\title{
Current Situation and Countermeasures of Education Reform in Application Oriented University in the New Period
}

\author{
Shuqin Liu \\ School of Life Science \\ BaiCheng Normal University \\ Baicheng Jilin Province, China 137000
}

\author{
Zhenxing Luo \\ Baicheng Academy of Forestry Science \\ Baicheng Jilin Province China 137000
}

\begin{abstract}
With the gradual deepening of China's education reform, the situation of college education reform has fallen into a very severe situation. Application oriented universities are supposed to follow the pace of the times based on education reform trends. For instance, they should strengthen education reform, change the traditional talent training model, and implement innovative education. Besides, they should also improve the education quality of application oriented universities and promote the stable development of colleges and universities. This work first pointed out the problems existing in the education reform of application oriented universities in China and analyzed them, and then put forward effective countermeasures for the education reform of application oriented universities. This work offered an important theoretical basis for the education reform of application oriented universities in the new era.
\end{abstract}

Keywords-Application oriented university; Education reform; Reform countermeasures

\section{INTRODUCTION}

With the rapid development of China's economy and culture, the public's thoughts and values have undergone tremendous changes. In the new era, the requirements of social workers in various industries have gradually improved, and the requirements for contemporary college graduates are more comprehensive. In the new era, application oriented universities should carry out in-depth reform from the aspects of teaching objectives, teaching concepts, curriculum arrangement, teaching strength and teaching methods. Therefore, it can highlight the characteristics of the times and the deep integration of higher education at the present stage, promote the education reform of application oriented universities, and improve the education and management efficiency of undergraduate colleges and universities [1]. At present, the society urgently needs compound talents with comprehensive qualities. It also needs college graduates with professional skills and professional qualities. Application oriented universities should start from multiple angles and improve the comprehensive quality of application oriented university students, so as to ensure the smooth employment of graduates and provide quality talents for all walks of life

Project: Jilin province 12th five-year plan education department project (No.24, 2016), Jilin provincial science and technology department planning project (20160414012GH), Core model course project of bachelor's degree of Baicheng Normal University development and enterprise production.

\section{NeCESSITY AND VALUE OF EDUCATION REFORM IN COLLEGES AND UNIVERSITIES}

\section{A. Education reform is suitable for the development of the times}

The teaching reform in application oriented universities is mainly to meet the economic, political and cultural development, satisfying the needs of talents in various industries in the new era. In the application oriented universities, comprehensively promoting education reform can help improve the adaptability of undergraduate colleges and universities, assist colleges and universities to serve urban development and nation building, and help to cultivate comprehensive talents in the new era [2]. There are some differences between application oriented universities and other universities. Compared with other universities, there are more application majors in application oriented universities, and the professional teaching focus more on the cultivation of students' professional ability and professional skills. Strengthening education reform is a subversion of traditional education reform, which helps to connect businesses and universities.

\section{B. Education reform helps to improve the quality of education}

In recent years, China has put forward the development strategy of "invigorating China through science and education". It can be seen that China attaches great importance to the development of higher education. Education is the sharpest weapon of the country and an effective way to improve the quality of national citizens. Therefore, it is of vital importance to improve the quality of education in colleges and universities. Promoting the education reform of colleges and universities can improve the teaching quality of application oriented universities. The reform of higher education is not only in the concept of education, but also from the specific teaching curriculum, teaching content, teaching methods, teacher strength and teaching assessment methods [3].

\section{Education reform helps to cultivate professionals}

The education reform of application oriented universities helps to achieve the cultivation of compound talents. There are certain differences between applications oriented universities 
and ordinary universities. The main manifestations are that application oriented universities have more application majors, and their education and teaching tend to be professional, which helps to improve students' professional business ability and professional skills. Therefore, students are more likely to successfully achieve employment and improve their comprehensive ability and quality after graduation, which is also the ultimate goal of the education reform in application oriented universities.

\section{Education reform helps to improve the innovation of talent cultivation mode}

The education reform of application oriented universities is an inevitable requirement for the development of colleges and universities in the new era, and an effective way to cultivate high-quality comprehensive talents. The promotion of the education reform in application oriented universities is not only the behavior and process of innovative educational concepts in colleges and universities, but most the important focus on the talent's cultivation. Education in colleges and universities should pay attention to students' practical ability and innovative ability, and encourage students to play their individuality. Nowadays, due to the fierce social competition, traditional talent training is not suitable, therefore, it is necessary to promote the process of education reform and cultivate the overall quality of students.

\section{Problems Existing IN the EduCATiON OF ApPlicAtion ORIENTED UNIVERSITIES}

\section{A. Concepts in some colleges and universities are relatively lagging behind}

The purpose of the application oriented universities is to train professionals for the national society, so it is necessary to attach importance to the cultivation of students' basic theoretical knowledge and professional skills. However, in the actual teaching process, the teaching philosophy and guiding ideology are relatively lagging behind. Many educational concepts have not followed the development of the times, leading to some misunderstandings in teaching and management concepts [4]. Especially in the context of innovation and entrepreneurship society, application oriented universities reflect certain drawbacks, such as insufficient teaching innovation. They simply believe that the ultimate goal of education is to promote employment, but they neglect the cultivation of students' professional ability and overall quality. Consequently, teaching management in some colleges and universities is not strict enough and the advanced concepts and ideas are not integrated into the teaching, resulting in low teaching quality and the student education system is difficult to form in a short time. Moreover, application oriented universities have been influenced by traditional educational concepts for many years, and it is not an easy task to update educational awareness in a short period of time.

\section{B. The education and teaching model of colleges and universities is not scientific enough}

At present, many application oriented universities in China generally adopt relatively traditional teaching mode for teaching. Some teachers still use indoctrinating and cramming teaching methods to carry out teaching. Students are in a relatively passive position, and students' subjective initiative has not been played out. The quality of teaching in each major is difficult to improve [5]. The teaching mode of application oriented universities is related to the improvement of campus education quality, which is related to the improvement of students' comprehensive quality. However, the reality is that some application oriented universities have not been scientific enough, and teachers have not adopted appropriate teaching methods for teaching, as a result, it is difficult for students to understand and digest the knowledge they have learned, and it is more difficult to internalize into their own abilities. Moreover, professional teaching in some colleges and universities is not closely related to the local economy and culture, which makes it difficult for application oriented education to serve the local economy. This is one of the issues that should be considered by application oriented universities.

\section{Curriculum arrangement in some application oriented universities is not reasonable enough}

The development of dual-education education in China started late, and there are still many problems existing in the curriculum system of innovation and entrepreneurship in most application oriented universities. For one thing, the curriculum system is divided into public basic courses, public elective courses and professional elective courses. Most institutions have set up innovative and entrepreneurial courses as elective courses or social practice courses, with insufficient attention. For another, the professionalism of the curriculum is not prominent enough. Different majors have different requirements and characteristics, and their innovative and entrepreneurial methods are not the same. Many institutions carry out lecture-based teaching forms when they carry out innovative and entrepreneurial teaching activities. They do not combine professional features and professionalism is not prominent. There are fewer institutions that implement innovative entrepreneurship courses that reflect professional foundations and professional orientations.

\section{The assessment mechanism in application oriented universities is not advanced enough}

Application oriented universities follow the traditional assessment mode mainly based on examinations. This resultbased assessment method lacks comprehensive and dynamic assessment and evaluation, so it is difficult to assess students from various angles and examine students' abilities and comprehensive quality. The assessment in application oriented universities should be combined with the development of the times. It is necessary to establish a process-based and dynamic student assessment and evaluation mechanism, emphasizing the importance of students' lifelong learning and their daily performance, and attaching importance to students' ability tests, including various activities and competitions in or out school, graduation design and entrepreneurship competitions. 


\section{E. Application oriented universities do not strengthen integration and contact with enterprises}

Application oriented universities are different from traditional colleges and universities. It should start from the perspective of application majors and pay attention to the application ability and professionalism of students. In order to reflect the professional ability of professional education, it is necessary to attach importance to the relationship and cooperation between schools and enterprises. However, the actual situation is that some application oriented universities are not closely connected with the enterprise, and the cooperation is not deep enough. The lack of a practical teaching system of integrating production with learning and research has made it difficult for students to improve their ability in a short period of time, which has affected the cultivation of comprehensive quality of college graduates.

\section{EFFECTIVE COUNTERMEASURES FOR THE EDUCATION REFORM OF APPLICATION ORIENTED UNIVERSITIES}

\section{A. Establishing scientific educational concepts and teaching objectives}

First of all, it is necessary to optimize the professional structure of application oriented universities and establish scientific teaching goals. In the formulation of teaching objectives, teachers should do a good job in educational theory research, grasp the characteristics of the times, and pay attention to the professional talent requirements of various industries at current stage. It is necessary to analyze the professional skills of workers in various industries or fields, so as to determine the direction of personnel training and then improve the arrangement of teaching objectives. Secondly, it is necessary to fully consider the important role of higher education in the local economic development. It is supposed to dynamically adjust the methods and methods in light of market requirements, advance with the times, and cultivate compound talents with professional competence. Application oriented universities should consider a wide range of needs based on the current situation, combine local economic development strategies and education systems, establish a scientific education system, clarify the goal of talent training, realize the timely updating of educational concepts, and promote the sound development of college education.

\section{B. Promoting the education mode reform of application oriented universities}

At present, the development of various industries in China has higher and higher requirements for the practical ability and professional quality of college students. However, with the development of science and technology, the knowledge systems in various fields are changing faster and faster. Therefore, application oriented universities have to start from multiple angles. The reform of innovative education modes should transform traditional concepts and promote the gradual advancement of education reform. At present, the textbooks used by application oriented universities are slow to update, and many educational contents are separated from the actual production of the society. Relevant departments should start with the textbooks, increase the intensity of textbook reform, organize professionals to write innovative textbooks, and improve the combination of teaching content with actual production, so as to improve the scientific and practical content of teaching. In addition, teachers should adopt a variety of teaching methods to enrich teaching forms, such as using multimedia teaching techniques to improve the quality and efficiency of education and teaching, and holding more teaching activities and various competitions, including campus knowledge competition, industrial design, advertising design competition and fashion design competition. These activities can improve students' sense of competition and practical ability, promote comprehensive quality, guarantee their employment after graduation, and provide intellectual support for their careers.

\section{Improving the curriculum system in application oriented universities}

Application oriented universities should perfect the theoretical teaching and practical teaching curriculum system, ensuring that students are taught according to their aptitude. They should also highlight the professional characteristics and advantages of application oriented universities by strengthening their practical curriculum of theoretical courses. Application oriented universities should build a suitable curriculum system based on the development of local economy and industrial needs. The curriculum of colleges and universities should be combined with the development of the times and the cultivation of professional talents. It is necessary to set up practical courses of theoretical courses in combination with the established teaching objectives and teaching concepts. The content of the courses should be arranged and set. Moreover, application oriented universities should stimulate students' interest, pay attention to cultivating students' ability of innovation and entrepreneurship, and ensure that education meets the requirements of the times and industry needs. They are supposed to break through the shackles of traditional educational concepts, improve teaching content, and link theoretical courses with practical courses together, so as to highlight the professional attributes of application professional education. For example, in the advertising design profession, the application teaching of CAD graphic design technology and software should be strengthened, and advertising design activities should be regularly carried out to highlight students' application ability to CAD software, improve their graphic design level, and improve their practical ability and hands-on ability.

\section{Establishing a dynamic educational assessment system}

Application oriented universities should pay attention to the innovation of education evaluation and assessment mode in education and teaching, which should be combined with the actual teaching content and professional setting characteristics. The method of evaluation and assessment of the department should not be used as the only indicator to assess students. It is necessary to improve the evaluation indicators of college education and ensure the scientific nature of the indicators. Colleges and universities should adopt a comprehensive evaluation system, including moral education, intellectual education, physical education and ability assessment. Moral education and student's ability assessment are relatively 
abstract, which is difficult to use unified standards to measure. It is necessary to use a procedural and dynamic evaluation model for students to conduct evaluations and assessments, so as to master students' comprehensive abilities and literacy [6]. Application oriented universities should introduce a new evaluation mechanism, establish a reasonable evaluation mechanism, do a good job in social research based on industrial needs and basis, expand the quality assessment system for college students, and pay more attention to the improvement of students' practical ability and professional quality.

\section{E. Establishing a practical teaching system of integrating production with learning and research}

Application oriented universities should establish a platform for campus and enterprise cooperation, establish an educational mechanism of integrating production with learning and research, and combine the objectives of talent cultivation in application oriented universities to establish good relations with enterprises. It should also expand the scope of cooperation with enterprises and deepen cooperation with enterprises, for instance, the engineering management major should highlight the role of engineering management, and the combination of universities and engineering construction enterprises should build order training mechanism and cultivate professional engineering management talents [7]. What's more, it is necessary to strengthen the construction of training bases inside and outside the university, so as to highlight the importance of practical teaching and improve students' practical ability. Application oriented universities should rely on existing resources and investigate hardware and software conditions to increase investment and strengthen infrastructure construction. Moreover, teachers should be organized regularly to corporate training and learning in enterprises, and corporate management personnel and front-line backbone should be hired to teach in colleges and universities, so as establish a double-teacher team, which can improve teachers' professional ability and teaching level, promote the innovation of education mechanism in application oriented universities, and ensure the outcome of the reform.

\section{SUMMARY}

To sum up, application oriented universities should attach great importance to education reform, promote the rapid advancement of education reform, combine industry's requirements for talents, and adjust with application majors to re-determine the orientation of education. They should also focus on the innovation in teaching methods, improve the professional teaching ability and comprehensive quality of teachers, optimize the arrangement of theoretical and practical courses, establish a practical teaching system of integrating production with learning and research, and then cultivate highquality applied talents.

\section{REFERENCES}

[1] He Jinyu. Research on Collaborative Innovation and Collaborative Education Mode in Local New Undergraduate Colleges[M]. Jinan: Shandong University Press, 2013: 118.

[2] Wang Zhanren. The Overall Conception of the Concept of Innovative Education in Colleges and Universities[J]. China Higher Education Research, 2015, (07).

[3] Liu Ruidong. Exploring the Training Path of Dual-creation Talents in Colleges and Universities Under the Background of Industry-university Collaborative Education[J]. Chinese and Foreign Entrepreneurs, 2019 (10): 205.

[4] Xing Saipeng, Tao Meisheng. Research on the Construction of Teaching Staff System of Application Technology Undergraduate Universities Based on the Perspective of "Industry - education Integration and School - Enterprise Cooperation"[J]. Vocational Education Forum, 2014(29): 4 8.

[5] Gu Juping. Value and Mechanism of Collaborative Innovation in Practice Teaching in Local Universities[J]. China Higher Education Research, 2015, (10).

[6] Yang Yong. Problems and Countermeasures in College Education Reform[J]. Journal of Jiamusi Vocational College, 2015, 11: $232+234$

[7] Li Shuohao, Tao Wei. Review and Suggestion of China's Higher Education Reform Process[J]. Modern Education Management, 2017 (03): 1 - 9. 